\title{
A Blockade of IGF Signaling Sensitizes Human Ovarian Cancer Cells to the Anthelmintic Niclosamide-Induced Anti- Proliferative and Anticancer Activities
}

\author{
Youlin Deng ${ }^{a, b}$ Zhongliang Wang ${ }^{b, c}$ Fugui Zhangb,c Min Qiao ${ }^{b, c}$ Zhengjian Yan ${ }^{b, c}$ \\ Qiang Wei ${ }^{\mathrm{b}, c}$ Jing Wang ${ }^{\mathrm{b}, c}$ Hao Liu $^{\mathrm{b}, c}$ Jiaming Fann ${ }^{\mathrm{b}, \mathrm{c}}$ Yulong Zou ${ }^{\mathrm{b}, \mathrm{c}}$ Junyi Liao ${ }^{\mathrm{b}, \mathrm{c}}$ \\ Xue Hu $u^{b, c}$ Liqun Chen ${ }^{b, c}$ Xinyi Yub Rex C. Haydon ${ }^{b}$ Hue H. Luub Hongbo Qja \\ Tong-Chuan He $\mathrm{e}^{\mathrm{b}, \mathrm{c}}$ Junhui Zhang ${ }^{\mathrm{a}, \mathrm{b}}$
}

aDepartments of Obstetrics and Gynecology, and Physical Examination, the First Affiliated Hospital of Chongqing Medical University, Chongqing, China; ${ }^{b}$ Molecular Oncology Laboratory, Department of Orthopaedic Surgery and Rehabilitation Medicine, The University of Chicago Medical Center, Chicago, IL, USA; 'Ministry of Education Key Laboratory of Diagnostic Medicine, and the Affiliated Hospitals of Chongqing Medical University, Chongqing, China

\section{Key Words}

Ovarian cancer • Drug repurposing • Niclosamide $\cdot$ IGF signaling $\bullet$ IGF-1R • Cancer pathways - Cell signaling $\cdot$ Synergistic effect • Cancer therapy

\begin{abstract}
Background/Aims: Ovarian cancer is the most lethal gynecologic malignancy, and there is an unmet clinical need to develop new therapies. Although showing promising anticancer activity, Niclosamide may not be used as a monotherapy. We seek to investigate whether inhibiting IGF signaling potentiates Niclosamide's anticancer efficacy in human ovarian cancer cells. Methods: Cell proliferation and migration are assessed. Cell cycle progression and apoptosis are analyzed by flow cytometry. Inhibition of IGF signaling is accomplished by adenovirus-mediated expression of siRNAs targeting IGF-1R. Cancer-associated pathways are assessed using pathway-specific reporters. Subcutaneous xenograft model is used to determine anticancer activity. Results: We find that Niclosamide is highly effective on inhibiting cell proliferation, cell migration, and cell cycle progression, and inducing apoptosis in human ovarian cancer cells, possibly by targeting multiple signaling pathways involved in ELK1/SRF, AP-1, MYC/MAX and NFKB. Silencing IGF-1R exert a similar but weaker effect than that of Niclosamide's. However, silencing IGF-1R significantly sensitizes ovarian cancer cells to Niclosamide-induced anti-proliferative and anticancer activities both in vitro and in vivo. Conclusion: Niclosamide as a repurposed anticancer agent may be more efficacious when combined with agents that target other signaling pathways such as IGF signaling in the treatment of human cancers including ovarian cancer.
\end{abstract}

T.-C. He, MD, PhD

and Junhui Zhang, MD, PhD

KARGER
Molecular Oncology Laboratory, The University of Chicago Medical Center, 5841 South Maryland Avenue, MC 3079, Chicago, IL 60637, (USA); and Department of Obstetrics and Gynecology, The First Affiliated Hospital, Chongqing Medical University, Chongqing 400046, (China), E-Mail tche@uchicago.edu / 2275610878@qq.com 


\section{Cellular Physiology Cell Physiol Biochem 2016;39:871-888

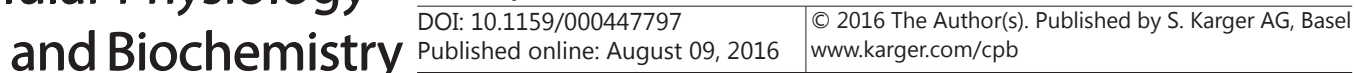 \\ Deng et al.: Repurposing Niclosamide as an Anti-Ovarian Cancer Agent}

\section{Introduction}

As the fifth most common cancer in women in the United States, ovarian cancer is the most deadly gynecologic malignancy $[1,2]$. Due ot the absence of an effective screening strategy, only approximately $20 \%$ of ovarian cancers are diagnosed while confined to the ovaries. Over the past two decades, the 5-year survival rate for ovarian cancer patients has substantially improved, largely due to improved surgical techniques and empirically optimized chemotherapy regimens of cytotoxic platinum-combination drugs. In spite of these improvements, the overall cure rate remains approximately $30 \%[1,3]$. Most patients experience recurrence within 12-24 months and die of progressively chemotherapy-resistant disease $[1,3]$. Clinical management of ovarian cancer has met many challenges, which is in part because the origin and pathogenesis of epithelial ovarian cancer (EOC) are poorly understood [2]. Epithelial ovarian cancer (EOC) is the most common subtype. Increasing evidence indicates that EOC itself is composed of a diverse group of tumors that can be further classified on the basis of distinctive morphologic and genetic features [1, 2, 4-6]. Increasing evidence indicates that noncoding RNAs and cancer stem cells may contribute to the progression and metastasis of ovarian cancers [7-10]. Given the heterogeneity of human ovarian cancers, significant improvements in long-term survival will hinge on translating recent insights into the molecular and cellular characteristics of ovarian cancers into personalized treatment strategies, optimizing methods of screening or early detection, and developing novel therapeutics. While significant progress has recently been made in the development of novel targeted therapies for human cancers, including ovarian cancers [1, $4-6,11]$, an effective alternative to drug development is repurposing drugs. Several examples of such drugs are currently in various stages of clinical trials $[12,13]$.

Repurposing clinically-used drugs represents a rapid and cost-effective approach to developing new anticancer agents. Niclosamide (trade name Niclocide) is a teniacide in the anthelmintic family and has been approved for use in humans for nearly 50 years. Niclosamide was thought to inhibit oxidative phosphorylation and stimulates adenosine triphosphatase activity in the mitochondria of cestodes (e.g. tapeworm), killing the scolex and proximal segments of the tapeworm both in vitro and/or in vivo, which is well tolerated in humans [14]. Niclosamide was identified as potential anticancer agent by various highthroughput screening campaigns [14]. It has been shown that Niclosamide exhibits effective anticancer activity and inhibits the growth of colon rectal cancer [15-17], osteosarcoma [18], lung cancer [19,20], breast cancer [21-24], prostate cancer [21, 25], glioblastoma [26], head and neck cancer [27], leukemia [28, 29], human uterine leiomyoma [30], and ovarian cancer [31-33]. Nonetheless, Niclosamide may not be used as a single agent therapy for any human cancers including ovarian cancer. We have recently demonstrated that Niclosamide may exert its anticancer activity by targeting multiple signaling pathways in human osteosarcoma [18]. Thus, it is important to investigate whether blockades of other signaling pathways will potentiate or augment the Niclosamide's anticancer activity.

In this study, we investigate whether the anticancer activity of Niclosamide can be potentiated by inhibiting IGF signaling in human ovarian cancer cells. We find that Niclosamide is highly effective on inhibiting cell proliferation, cell migration, and cell cycle progression, and inducing apoptosis in human ovarian cancer cells. Silencing IGF1R exerts a similar but weaker effect than that of Niclosamide's. However, silencing IGF1R significantly sensitizes ovarian cancer cells to Niclosamide-induced anti-proliferative and anticancer activities both in vitro and in vivo. Therefore, our findings strongly suggest that Niclosamide as a repurposed anticancer agent may be more efficacious when combined with agents that target other signaling pathways such as IGF signaling in the treatment of human cancers including ovarian cancer. 


\section{Cellular Physiology Cell Physiol Biochem 2016;39:871-888

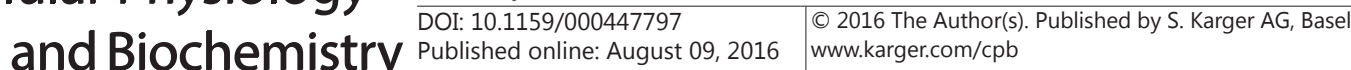 \\ Deng et al.: Repurposing Niclosamide as an Anti-Ovarian Cancer Agent}

\section{Materials and Methods}

\section{Cell culture and chemicals}

Human ovarian cancer cell lines SKOV3 and HeyA8 were provided by Dr. Ernest Lengyel. HEK-293 cells were from ATCC (Manassas, VA). HEK-293 derivative line 293pTP was previously reported [34]. These lines were maintained in complete Dulbecco's Modified Eagle's Medium (DMEM) containing 10\% fetal bovine serum (FBS, Invitrogen, Carlsbad, CA), 100 units of penicillin and $100 \mu \mathrm{g}$ of streptomycin at $37^{\circ} \mathrm{C}$ in $5 \% \mathrm{CO}_{2}$ as described [35-37]. Niclosamide was purchased from Cayman Chemical (Ann Arbor, MI), and cisplatin was purchased from Sigma-Aldrich (St. Louis, MO). Unless indicated otherwise, all chemicals were purchased from Thermo-Fisher Scientific (Waltham, MA).

\section{Viable cell counting assay}

Viable cells were counted with Trypan blue exclusion staining assay as described [38]. Briefly, subconfluent SKOV3 and HeyA8 cells were treated with Niclosamide at the indicated concentrations or vehicle control. At $24 \mathrm{~h}$ and $48 \mathrm{~h}$, cells were trypsinized, collected and stained with Trypan blue $0.1 \%$ Trypan blue). Unstained viable cells were counted under a bright field microscope. Each assay condition was done in triplicate.

Crystal violet cell viability assay

Crystal violet staining assay was conducted as described [39-41]. Briefly, subconfluent HeyA8 and/ or SKOV3 cells were treated with varied conditions. At the indicated time after treatment, cells were gently washed with PBS and stained with $0.5 \%$ crystal violet/formalin solution at room temperature for 20-30min. The stained cells were washed with tape water and air dried for taking macrographic images $[42,43]$.

\section{WST-1 cell proliferation assay}

Cell proliferation was assessed by using Premixed WST-1 Reagent (Clontech, Mountain View, CA) as described $[36,44]$. Briefly, subconfluent SKOV3 and HeyA8 cells seeded in 96-well plates were treated with varied conditions. At the indicated time points, the Premixed WST-1 Reagent was added to each well, followed by incubating at $37^{\circ} \mathrm{C}$ for $1-3 \mathrm{~h}$ and reading at $440 \mathrm{~nm}$ using the microplate reader (BioTek EL800, Winooski, VT). Each assay condition was done in triplicate.

\section{Cell wounding/migration assay}

Cell wounding/migration assay was performed as described $[45,46]$. Briefly, exponentially growing ovarian cancer cells were seeded in 6-well cell culture plates and allowed to reach approximately $90 \%$ confluence. Then, the monolayer cells were wounded with sterile micro-pipette tips. At various time points, the wound healing status at the approximately same locations was recorded under bright field microscopy. Each assay condition was done in triplicate.

\section{Apoptosis analysis (Hoechst 33258 staining)}

As previously described [18, 42], exponentially growing HeyA8 and SKOV3 cells were treated with varied conditions. At $24 \mathrm{~h}$ post treatment, cells were collected, fixed and stained with the Magic Solution (10x stock: $0.5 \%$ NP-40, 3.4\% formaldehyde, $10 \mathrm{~g} / \mathrm{ml}$ Hoechst 33258, in PBS). Apoptotic cells were examined and recorded under a fluorescence microscope. Each assay condition was done in triplicate. The results were repeated at least in three independent batches of experiments. The average numbers of apoptotic cells were calculated by counting apparent apoptotic cells in at least ten random fields at 100x magnification for each assay condition.

\section{Cell cycle analysis}

The exponentially growing HeyA8 and SKOV3 cells were seeded in 6-well plates at sub-confluence and treated with varied conditions. At $24 \mathrm{~h}$ or $48 \mathrm{~h}$ post treatment, cells were collected, fixed and stained with the Magic Solution for 30min. The stained cells were subjected to flow cytometry analysis using the BD FACSCalibur-HTS, as described [46]. The acquired flow cytometry data were analyzed with the FlowJo v10.0 software. Each assay condition was done in triplicate. 


\section{Cellular Physiology Cell Physiol Biochem 2016;39:871-888 \begin{tabular}{ll|l} 
DOI: 10.1159/000447797 & $\begin{array}{l}\text { O 2016 The Author(s). Published by S. Karger AG, Basel } \\
\text { www.karger.com/cpb }\end{array}$ \\
\hline
\end{tabular} \\ Deng et al.: Repurposing Niclosamide as an Anti-Ovarian Cancer Agent}

Construction and amplification of recombinant adenovirus expressing siIGF1R or RGFP

Recombinant adenovirus expressing siRNAs targeting human IGF-1R coding region was constructed by using the AdEasy system as described [47-50]. Briefly, the siRNA target sites were designed by using the Dharmacon's siDESIGN web-based program, as previously reported [51-53]. The selected three human IGF1R-targeting siRNA sites are 5'-GGC CAG AAA TGG AGA ATA A -3'; 5'-CCA AGG GTG TGG TGA AAG A-3'; and 5'-TCT CAA GGA TAT TGG GCT T-3'. The siRNA sites were assembled into our recently developed adenoviral shuttle vector pAdTrace-OK through Gibson DNA assembly [52, 53], resulting in pAdTrace-siIGF1R, which expresses the three siRNAs in one vector. The pAdTrace-silGF1R shuttle vector was used to generate recombinant adenovirus in HEK-293 or 293pTP cells [34]. The resulting adenovirus was designated as AdRsiIGF1R, which also expresses RFP [54-57]. An analogous control adenovirus expressing a scrambled siRNA, as well as RFP and GFP (Ad-RGFP) was used as a control [58, 59]. For all adenoviral infections, polybrene $(4-8 \mu \mathrm{g} / \mathrm{ml})$ was added to enhance infection efficiency as previously reported [60].

\section{Cell transfection and pathway-specific luciferase reporter assay}

The Gaussia luciferase (GLuc) reporter assay was conducted as described [61, 62]. The 12 cancerrelate signaling pathway GLuc reporters were homemade and previously described [61], including NFAT,

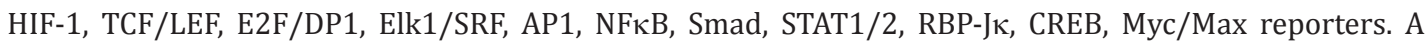
constitutively active reporter pG2Luc was used as a control $[18,63]$. Experimentally, subconfluent SKOV3 cells were seeded in $25 \mathrm{~cm}^{2}$ culture flasks and transfected with $3.0 \mu \mathrm{g}$ per flask of the 13 reporter plasmids using Lipofectamine (Invitrogen). At 16h post transfection, cells were replated in 12-well plates and treated with various concentrations of Niclosamide or DMSO control. At $24 \mathrm{~h}, 48 \mathrm{~h}$ or $72 \mathrm{~h}$ post treatment, culture media were taken and subjected to Gaussia luciferase assays using the BioLux Gaussia Luciferase Assay Kit (New England Biolabs). Each assay condition was done in triplicate. Luciferase activity was normalized by total cellular protein concentrations among the samples.

\section{Total RNA isolation and touchdown-quantitative real-time PCR (TqPCR) analysis}

Subconfluent ovarian cancer cells were infected with AdR-siIGF1R for 48h. Total RNA was isolated from the treated cells by using TRIZOL Reagents (Invitrogen) and subjected to reverse transcription reactions with hexamer and M-MuLV reverse transcriptase (New England Biolabs, Ipswich, MA). The cDNA products were used as PCR templates. The qPCR primers were designed by using Primer3 program [64] and used to amplify human IGF1R: 5'-ATG ACA TTC CTG GGC CAG TG-3' and 5'-TAG CTT GGC CCC TCC ATA CT-3'. TqPCR were carried out by using the SYBR Green-based qPCR analysis on a CFX-Connect unit (Bio-Rad Laboratories, Hercules, CA) [65]. The qPCR reactions were done in triplicate. GAPDH was used as a reference gene.

\section{Xenograft tumors and Xenogen bioluminescence imaging}

The use and care of animals were approved by the Institutional Animal Care and Use Committee. All experimental procedures were carried out in accordance with the approved guidelines. Briefly, HeyA8 stably labeled with firefly luciferase (HeyA8-FLuc) was constructed with piggybac system [37, 43, 66]. Exponentially growing HeyA8-FLuc cells were infected with AdR-silGF1R or Ad-RGFP for 36h and collected, resuspended at $10^{7}$ cells $/ \mathrm{ml}$ and injected subcutaneously into the flanks of athymic nude mice (Harlan Laboratories, 6-8 week old, male, $10^{6}$ cells per injection, and 4-6 sites per mouse). The mice were divided into four groups ( $n=5$ per group). At three days post injection, the animals were treated with Niclosamide (10 mg/kg body weight) or vehicle control intraperitoneally once every two days. Tumor growth was monitored by whole body bioluminescence imaging using Xenogen IVIS 200 Imaging System weekly after treatment. The average signal for each group at different time points was calculated using the Xenogen's Living Image analysis software as reported [39, 41, 46].

\section{$H \&$ E staining}

The mice were sacrificed at the end of week 4 and subcutaneous tumor masses were retrieved and fixed in $10 \%$ buffered formalin, and embedded in paraffin. Serial sections of the embedded specimens were stained with hematoxylin and eosin (H \& E) as described $[59,67]$. 


\section{Cellular Physiology Cell Physiol Biochem 2016;39:871-888

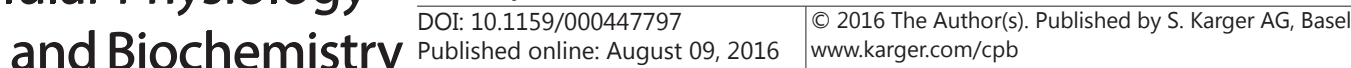

\section{Statistical analysis}

The quantitative assays were performed in triplicate and/or repeated three times. Statistical analysis was carried out using Microsoft Excel program. Data were expressed as mean \pm SD. Statistical significances were determined by one-way analysis of variance and the student's $t$ test. A value of $p<0.05$ was considered statistically significant.

\section{Results}

Niclosamide effectively inhibits cell proliferation of human ovarian cancer cells

We sought to test the effect of the antibiotic Niclosamide on the proliferative activity of two commonly-used human ovarian cancer lines HeyA8 and SKOV3. We found cell proliferation was significantly inhibited by Niclosamide at as low as $1 \mu \mathrm{M}$ in both HeyA8 and SKOV3 cells in a time course and dose-dependent fashion (Fig. 1a). When treated with $1 \mu \mathrm{M}$ Niclosamide, the viable cell counts decreased to $65 \%$ and $30.1 \%$ of the control groups' at $24 \mathrm{~h}$ and $48 \mathrm{~h}$, respectively, in HeyA8 cells (Fig. 1a-i). Similarly, for SKOV3 cells, treatment with $1 \mu \mathrm{M}$ Niclosamide led to a decrease in viable cells to $53.4 \%$ and $36 \%$ of the control group's at $24 \mathrm{~h}$ and $48 \mathrm{~h}$, respectively (Fig. 1a-ii). These results were further confirmed by WST-1 proliferation assay (Fig. 1b). Specifically, when HeyA8 cells were treated with $1 \mu \mathrm{M}$ Niclosamide, cell proliferation rate reduced to $79.3 \%, 48.3 \%$, and $39.3 \%$ of the control's at $24 \mathrm{~h}, 48$, and $72 \mathrm{~h}$ post treatment, whereas the two later time points are statistically significant (Fig.1b-i). The cell proliferation of HeyA8 cells was effectively inhibited by Niclosamide in time and dose-dependent fashion and almost completely inhibited at $8 \mu \mathrm{M}$ (Fig.1b-i). A

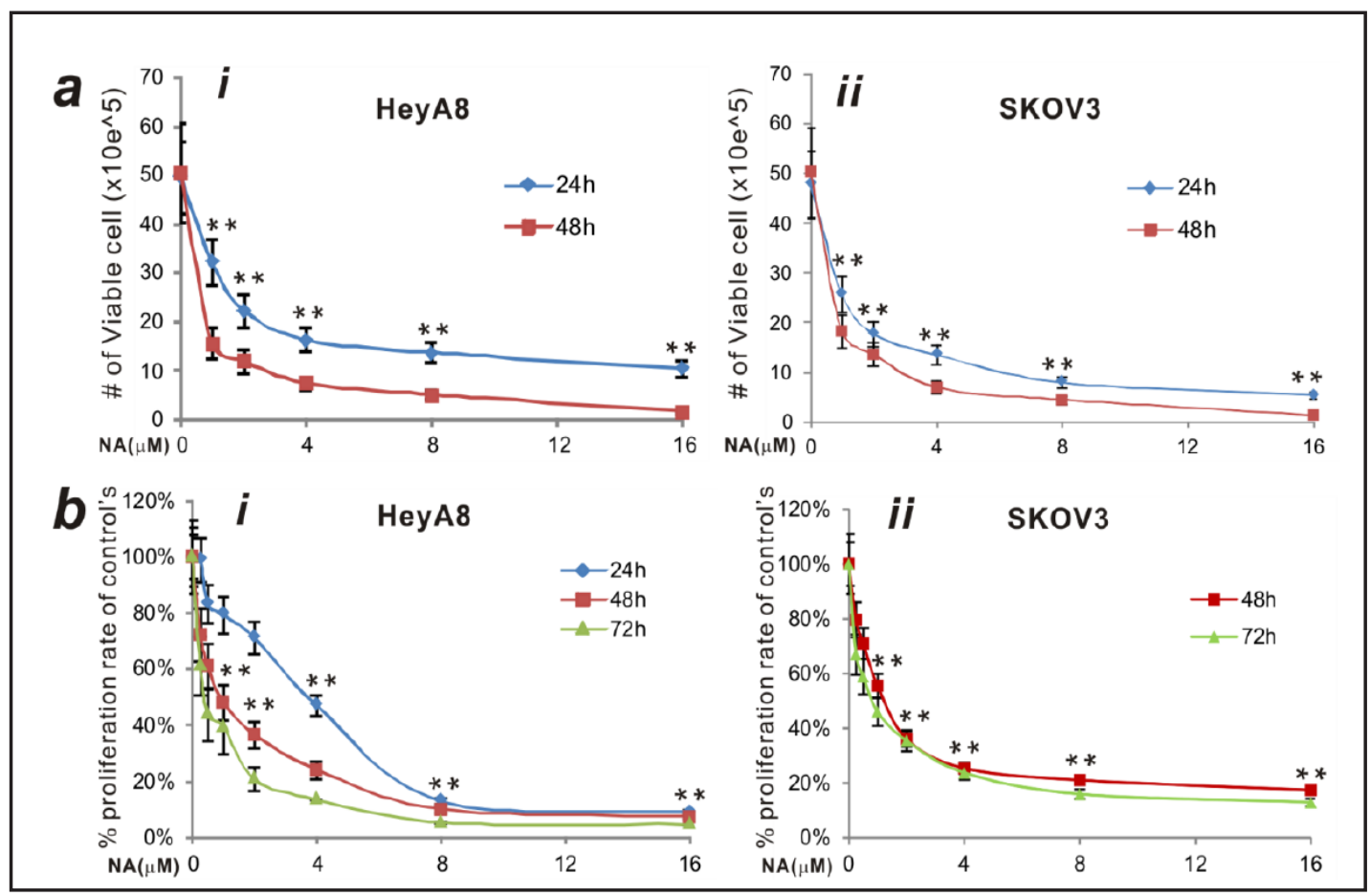

Fig. 1. Niclosamide effectively inhibits the proliferation of human ovarian cancer cells. (a) Viable cell counting assay. Subconfluent HeyA8 (i) and SKOV3 (ii) cells were seeded in 12-well plates and treated with Niclosamide at the indicated concentrations. At $24 \mathrm{~h}$ and $48 \mathrm{~h}$ post treatment, the viable cells were collected, stained with trypan blue and counted under a bright field microscope. (b) WST-1 cell proliferation assay. Subconfluent HeyA8 ( $i$ ) and SKOV3 (ii) cells were seeded in 96-well plates and treated with Niclosamide at the indicated concentrations. At the indicated time points post treatment, the WST-1 reagent was added to plates and incubated for $1 \mathrm{~h}$ and absorbance measurement was performed. All assay conditions were done in triplicate. 


\section{Cellular Physiology \begin{tabular}{l|l|l}
\hline and Biochemistry 10.1159/000447797 & $\begin{array}{l}\text { ( ) 2016 The Author(s). Published by S. Karger AG, Basel } \\
\text { www.karger.com/cpb }\end{array}$
\end{tabular}

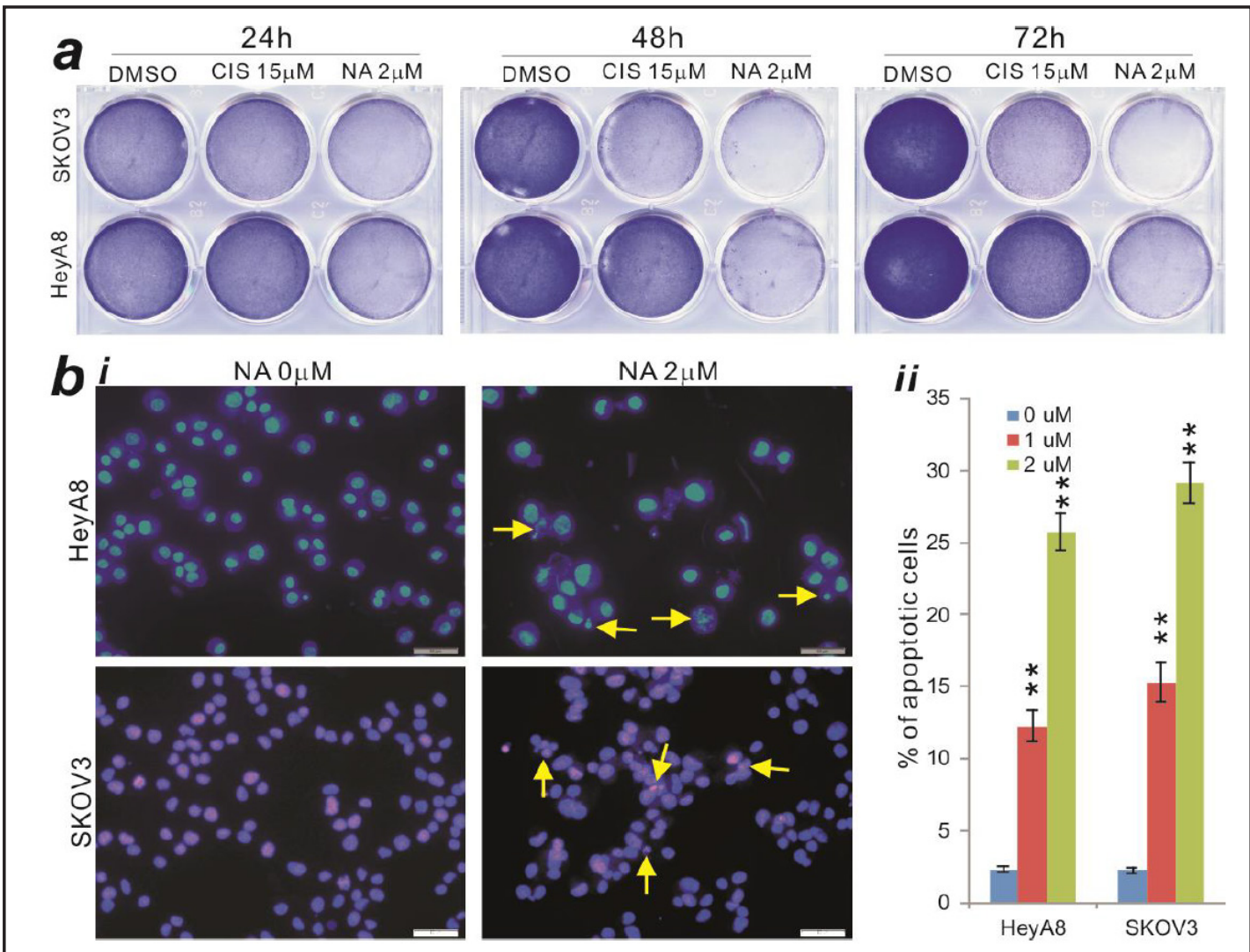

Fig. 2. Niclosamide induces apoptosis in human ovarian cancer cells. (a) Crystal violet staining assay. Subconfluent HeyA8 and SKOV3 cells were seeded in 12-well plates and treated with $2 \mu \mathrm{M}$ Niclosamide, $15 \mu \mathrm{M}$ cisplatin (CIS), or DMSO. At $24 \mathrm{~h}, 48 \mathrm{~h}$ and $72 \mathrm{~h}$ post treatment, the cells were fixed and stained with crystal violet. (b) Hoechst 33258 staining assay. Subconfluent HeyA8 and SKOV3 cells were treated with 1 or $2 \mu \mathrm{M}$ Niclosamide or solvent control. At $24 \mathrm{~h}$ post treatment, cells were collected, fixed and stained with Hoechst 33258 and examined under a fluorescence microscope (i). Apparent apoptotic cells (indicated by arrows) were counted in at least 10 random fields under $100 \mathrm{x}$ magnification (ii). “**” $\mathrm{p}<0.01$ (Niclosamide treated vs. control group).

similar trend was observed in SKOV3 cells as $1-2 \mu \mathrm{M}$ Niclosamide was shown to effectively inhibit cell proliferation at $48 \mathrm{~h}$ and $72 \mathrm{~h}$ post treatment (Fig.1b-ii). These results indicate that Niclosamide can effectively inhibit cell proliferation of human ovarian cancer cells.

Niclosamide is highly cytotoxic and induces apoptosis in human ovarian cancer cells

We conducted Crystal violet staining to compare the cytoxicity between Niclosamide and the clinical cancer drug cisplatin. We found that $2 \mu \mathrm{M}$ Niclosamide exhibited similar cytotoxicity at $24 \mathrm{~h}$ and $48 \mathrm{~h}$, but higher cytotoxicity at $72 \mathrm{~h}$ than that of $15 \mu \mathrm{M}$ cisplatin in SKOV3 cells (Fig. 2a). HeyA8 cells were seemingly more resistant to cisplatin as significant portion of viable cells were observed at $72 \mathrm{~h}$ post $15 \mu \mathrm{M}$ cisplatin treatment, while Niclosamide was shown to effectively inhibit cell proliferation at 72h (Fig. 2a).

We further investigated if Niclosamide can induce apoptosis in ovarian cancer cells. When HeyA8 and SKOV3 cells were treated with $0 \mu \mathrm{M}$ or $2 \mu \mathrm{M}$ Niclosamide for $24 \mathrm{~h}$ and stained with Hoechst 33258, significant numbers of apoptotic cells were observed (Fig. 2bi). Quantitative analysis indicated that the percentages of apoptotic cells were significantly increased in Niclosamide treated HeyA8 and SKOV3 cells ( $p<0.01)$ (Fig. 2b-ii). These results indicate that Niclosamide exhibits higher cytotoxicity than cisplatin and effectively induces apoptosis in human ovarian cancer cells. 


\section{Cellular Physiology Cell Physiol Biochem 2016;39:871-888 \begin{tabular}{l|l} 
and Biochemistry & DOI: 10.1159/000447797 \\
Published online: August 09, 2016 & $\begin{array}{l}\text { (c) } 2016 \text { The Author(s). Published by S. Karger AG, Basel } \\
\text { www.karger.com/cpb }\end{array}$
\end{tabular}

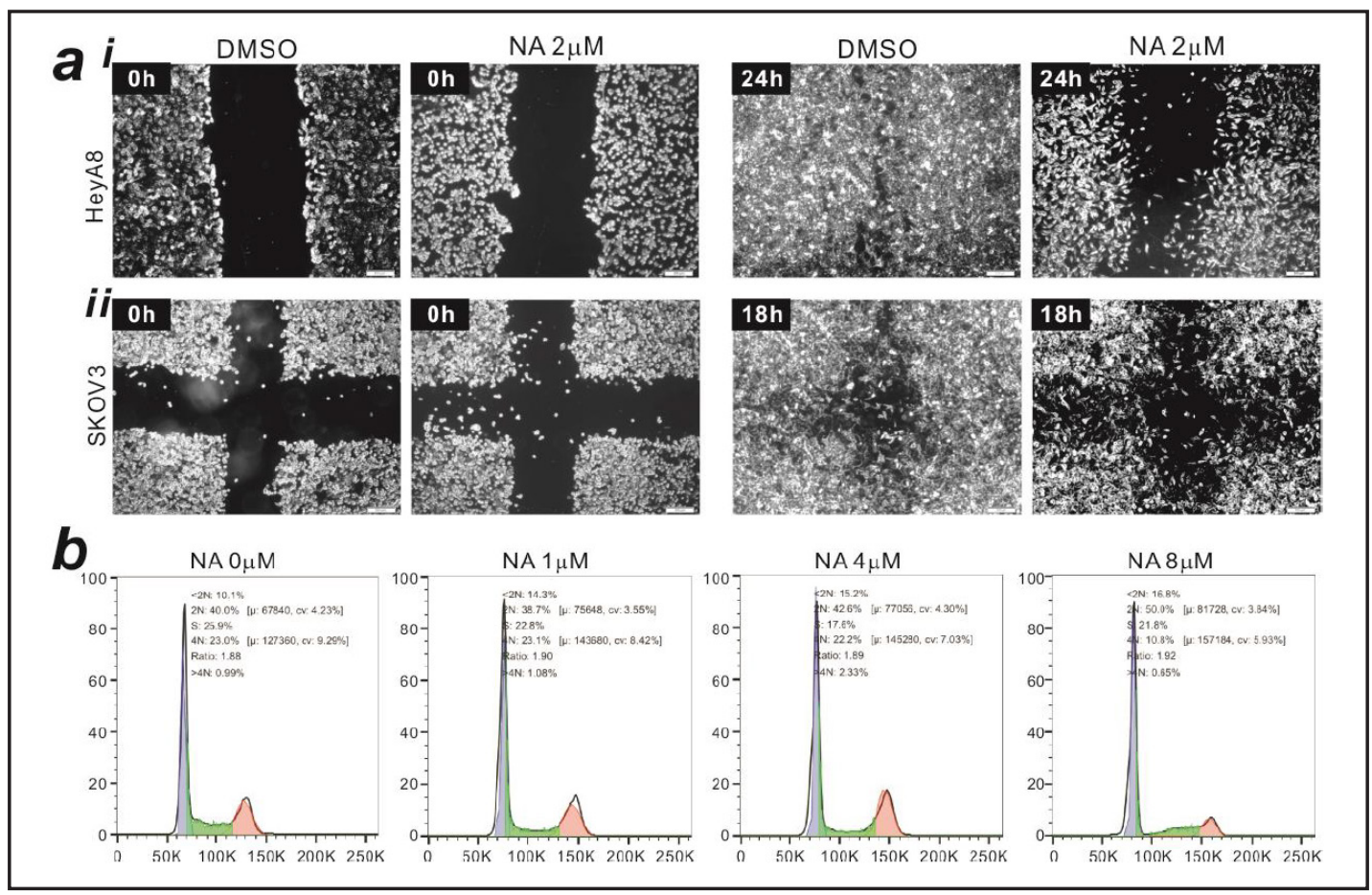

Fig. 3. Niclosamide inhibits cell migration and cell cycle progression in human ovarian cancer cells. (a) Cell wounding assay. Freshly seeded subconfluent HeyA8 (i) and SKOV3 (ii) cells were wounded with micro-pipette tips and treated with $2 \mu \mathrm{M}$ Niclosamide. The wounding gaps were recorded at the indicated time points after Niclosamide treatment. Each assay condition was done in triplicate. (b) Cell cycle analysis. Subconfluent HeyA8 cells were treated with Niclosamide or vehicle control for $24 \mathrm{~h}$. Cells were collected, fixed, stained with Hoechst 33258, and subjected to FACS analysis. Similar results were obtained in SKOV3 cells (data not included). Each assay condition was done in triplicate.

Niclosamide inhibits cell migration and cell cycle progression in human ovarian cancer cells

We next examined if Niclosamide exerts any effect on cell migration and wound healing in ovarian cancer cells. When freshly confluent HeyA8 monolayer cells were wounded, the gap was almost completely closed in DMSO control group, but the cells treated with $2 \mu \mathrm{M}$ Niclosamide failed to close the gap at 24h (Fig. 3a-i). Similar results were observed in SKOV3 monolayer cells, where control group closed the gap at around 18h, but approximately $75 \%$ of the gap remained open in the $2 \mu \mathrm{M}$ Niclosamide group Fig. 3a-ii). The rate of gap closures was further decreased when the cells were exposed to $4 \mu \mathrm{M}$ Niclosamide (data not shown). The above results suggest that Niclosamide may significantly inhibit cell proliferation and migration. We also performed cell cycle analysis on Niclosamide-treated cells and found a significant increase in the numbers of cells arrested in G1 phase, as well as decreased numbers of cells in S/M phase in Niclosamide-treated HeyA8 cells relative to the controls (Fig. 3b). Similar results were obtained in Niclosamide-treated SKOV3 cells (data not shown). These results suggest that Niclosamide's inhibition of ovarian cancer cell proliferation may be due in part to induction of apoptosis and inhibition of cell cycle progression.

Niclosamide inhibits multiple cancer-related signaling pathways, including the downstream effectors of IGF signaling

It has been reported that Niclosamide may exert anti-cancer activity in cancer cells by inhibiting $W n t / \beta$-catenin activity [68]. Although $W n t / \beta$-catenin signaling may play an important role in cancer development [69-71], our previous studies demonstrated low levels of endogenous Wnt/ $\beta$-catenin activity in HeyA8 and SKOV3 cells, which can be activated

\section{KARGER}



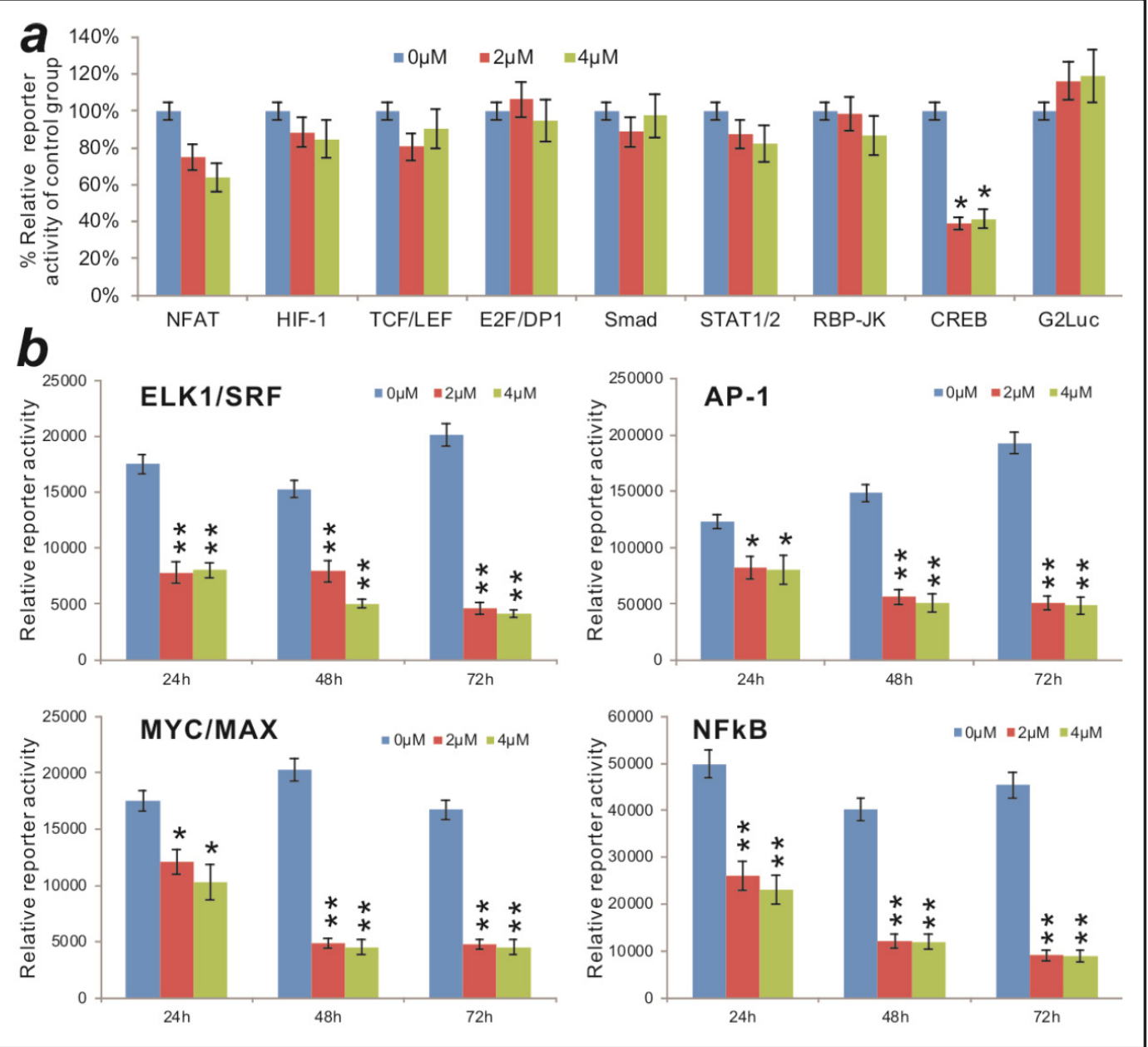

Fig. 4. Niclosamide inhibits multiple cancer-associated signaling pathways, including downstream mediators of IGF signaling. Subconfluent SKOV3 cells were transfected with the homemade GLuc reporters for the 12 cancer-associated pathways and a constitutively active reporter pG2Luc. At 16h post transfection the cells were treated with varied concentrations of Niclosamide. At $24 \mathrm{~h}, 48 \mathrm{~h}$ and $72 \mathrm{~h}$ after treatment, $50 \mu \mathrm{l}$ of the culture medium were collected for GLuc activity assay using BioLux GLuc Assay Kit. (a) Niclosamide does not significantly affect 8 of the 12 cancer-associated pathway reporters ( $72 \mathrm{~h}$ data point shown). (b) Niclosamide significantly inhibits the reporter activities of the 4 cancer-associated pathways. Each assay condition was done in triplicate. “*” $\mathrm{p}<0.05$, “**” $\mathrm{p}<0.001$.

by exogenous Wnt molecules [63]. Furthermore, it's conceivable that Niclosamide may target multiple signaling pathways to achieve its anticancer activity. Therefore, we sought to determine which, if any, cancer-associated pathways were modulated by Niclosamide. By introducing a panel GLuc reporters for 12 cancer-associated pathways as described [18, 42, $61,72]$, along with a constitutively active reporter pG2Luc, we found that in SKOV3 cells seven pathways, including NFAT, HIF-1, TCH/LEF, E2F/DP1, Smad, STAT1/2, and RBP-JK, were not significantly affected by Niclosamide at up to $4 \mu \mathrm{M}$ for $72 \mathrm{~h}$ treatment, while the CREB reporter was shown significantly inhibited at $72 \mathrm{~h}(\mathrm{p}<0.05)$ but not at $24 \mathrm{~h}$ and $48 \mathrm{~h}$ ( $>00.05$, data not shown) (Fig. 4a). However, four pathway reporters, including ELK1/ SRF, AP-1, MYC/MAX and NFKB, were significantly inhibited by Niclosamide at all three time points (Fig. 4b). Similar reporter assay results were obtained in HeyA8 cells (data not shown). These reporter results suggest that Niclosamide may mainly target growth factor signaling pathways. 


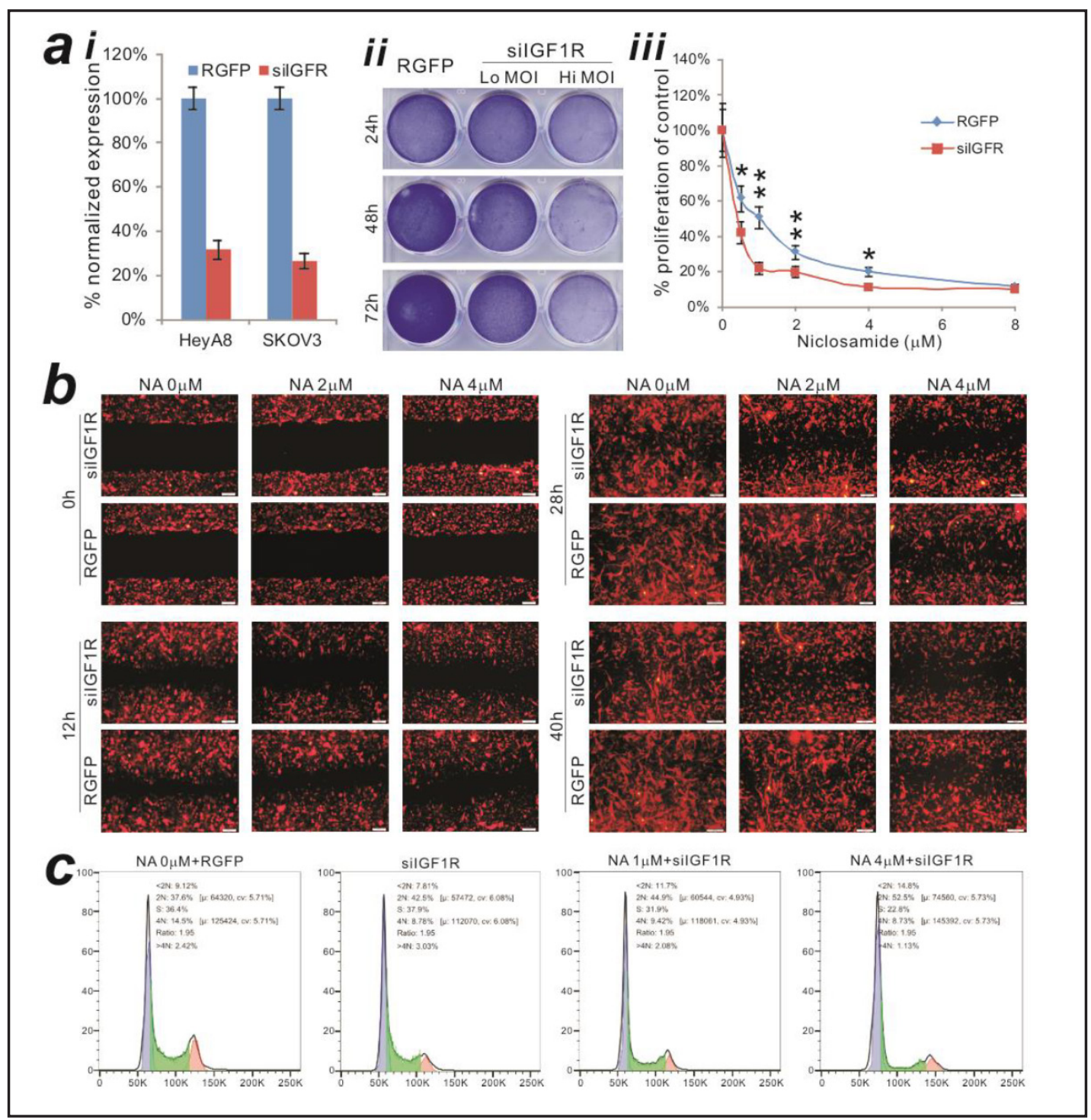

Fig. 5. Niclosamide synergizes with the silencing of IGF-1R expression in suppressing cell proliferation and migration of human ovarian cancer cells. (a) Effective knockdown of IGF-1R expression enhances Niclosamide-mediated inhibition of cell proliferation. The silencing efficacy of AdR-siIGF1R was assessed by TqPCR in human ovarian cancer lines (i). AdR-IGF1R-mediated silencing of IGF-1R expression in HeyA8 cells inhibits cell proliferation in a dose-dependent fashion. Crystal violet stain was carried out at $72 \mathrm{~h}$ after infection. Lo MOI, lower multiplicity (10 infectious viral particles/cell); Hi MOI, higher multiplicity (20 infectious viral particles/cell). (iii) Silencing IGF1R expression potentiates Niclosamide-mediated inhibition of cell proliferation. HeyA8 cells were infected with AdR-IGF1R or Ad-RGFP for 16h, replated into 96-well plates, and treated with the indicated concentrations of Niclosamide. The WST-1 assay was conducted at $48 \mathrm{~h}$ post treatment. “*” $\mathrm{p}<0.05$, “**” $\mathrm{p}<0.001$ (siIGF1R vs. RGFP groups at the given concentration). (b) Cell wounding assay. Subconfluent HeyA8 cells were infected with AdR-silGF1R or Ad-RGFP for 16h and replated into 6-well plates. Freshly seeded near-confluent infected HeyA8 cells were wounded with micro-pipette tips

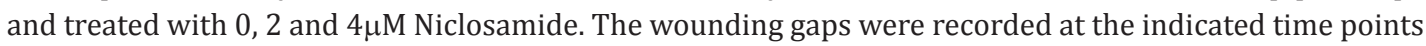
post Niclosamide treatment. Each assay condition was done in triplicate. (c) Niclosamide acts synergistically with silencing IGF-1R in suppressing cell cycle progression. Subconfluent SKOV3 cells were infected with AdR-siIGF1R or Ad-RGFP for 16h, replated into 6-well plates, and treated with Niclosamide at the indicated concentrations for $24 \mathrm{~h}$. Cells were collected, fixed, stained with Hoechst 33258, and subjected to FACS analysis. Each assay condition was done in triplicate. Representative results and selected combinations are shown. 


\section{Cellular Physiology Cell Physiol Biochem 2016;39:871-888

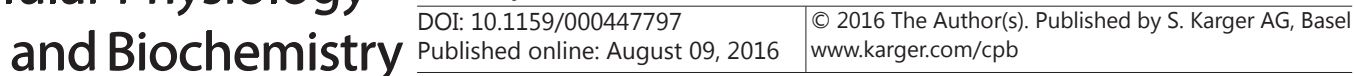

Deng et al.: Repurposing Niclosamide as an Anti-Ovarian Cancer Agent

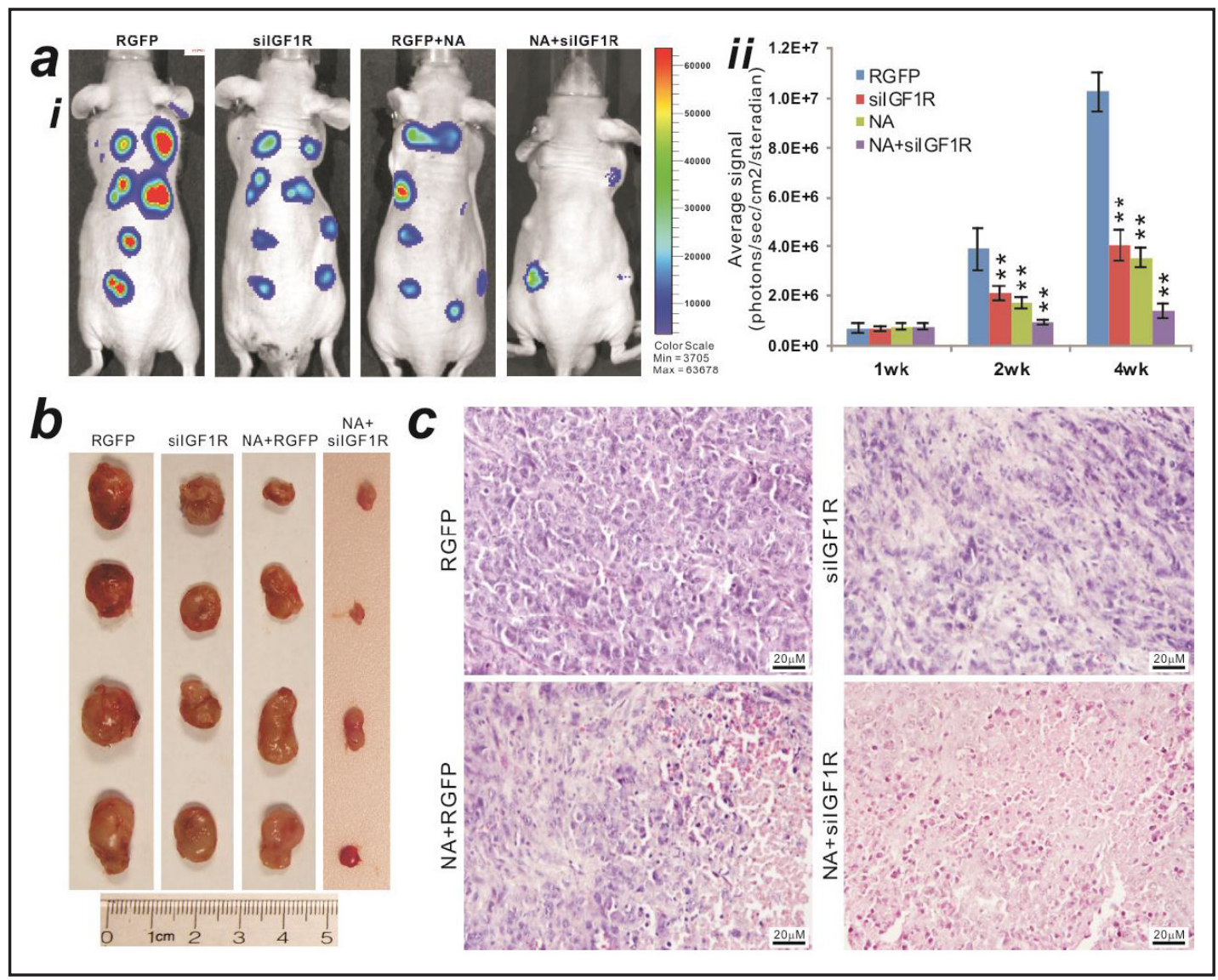

Fig. 6. A combination of Niclosamide and IGF-1R knockdown effectively inhibits tumor growth in the xenograft model of human ovarian cancer cells. (a) Xenogen bioluminescence imaging of xenograft tumor growth. Firefly luciferase-labeled HeyA8 cells were injected into athymic nude mice subcutaneously. At three days post injection, the animals were treated with Niclosamide $(10 \mathrm{mg} / \mathrm{kg})$ or vehicle control. The mice were imaged weakly after treatment, and sacrificed after 4 weeks. Representative images at week 2 are shown (i). The average signal for each group at different time points were calculated using the Xenogen's Living Image analysis software (ii). “**” $\mathrm{p}<0.001$ (treatment group vs. RGFP group). (b) Representative gross images of the retrieved tumor samples. (c) The retrieved tumor samples were paraffin-embedded, sectioned and subjected to $\mathrm{H} \&$ E staining. Representative results are shown.

Niclosamide synergizes with the silencing of IGF-1R expression in suppressing cell proliferation and migration of human ovarian cancer cells

IGF signaling is one of the most commonly activated growth factor signaling pathways in human cancers [73-75]. Most of the Niclosamide-targeted cancer pathways are either direct downstream of and/or related to the IGF signaling pathway. Thus, we examined if silencing IGF1R in human ovarian cancer cells would potentiate Niclosamide's antiproliferative activity. To accomplish efficient gene silencing of human IGF1R in ovarian cancers, we constructed the recombinant adenovirus AdR-siIGF1R, which expresses three siRNAs targeting IGF-1R coding region, based on our recently developed pSOK system [52]. AdR-siIGF1R was shown to effectively knock down IGF-1R expression in both HeyA8 and SKOV3 cells (Fig. 5a-i). Furthermore, AdR-IGF1R-mediated silencing of IGF-1R expression in HeyA8 cells inhibited cell proliferation in a dose-dependent fashion (Fig. 5a-ii), suggesting silencing IGF1R may exhibit modest anti-proliferation effect on ovarian cancer cells.

We further tested whether silencing IGF-1R would potentiate Niclosamide's growth inhibition activity. HeyA8 cells infected with AdR-siIGF1R were more sensitive to KARGER 
Nicloasamide as cell proliferation rate was significantly lower in AdR-siIGF1R-infected cells than that in Ad-RGFP control virus-infected cell at $0.5 \mu \mathrm{M}$ Niclosamide $(\mathrm{p}<0.05)$ (Fig. 5a-iii). More pronounced differences in terms of cell proliferation rates between AdR-siIGF1R and Ad-RGFP-infected cells were observed in $1.0 \mu \mathrm{M}$ and $2.0 \mu \mathrm{M}$ Niclosamide treatment groups (Fig. 5a-iii). Similar results were obtained from SKOV3 cells (data not shown). These results suggest that silencing IGF-1R may sensitize ovarian cancer cells to Niclosamide.

We also analyzed the effect of silencing IGF-1R on Niclosamide inhibited cell migration. Wounded HeyA8 monolayer cells infected with AdR-silGF1R showed a significant delay in gap closure in a Niclosamide dose-dependent fashion (Fig. 5b). For example, at $12 \mathrm{~h}$ and 28h, AdR-silGF1R-infected HeyA8 cells maintained much wider gaps, when treated with $2 \mu \mathrm{M}$ Niclosamide, than that of Ad-RGFP-infected cells' (Fig. 5b). Accordingly, we found that silencing IGF-1R in SKOV3 cells also enhanced the inhibitory effect of Nicosamide on cell cycle progression, as silencing IGF-R led to a significant increase in the numbers of cells in G1 phase and sub-G1 phase, as well as a decrease in the numbers of cells in S/G2 phases (Fig. 5c), which is consistent with the synergistic inhibitory effect between Niclosamide and silencing IGF-1R on cell proliferation in human ovarian cancer cells.

Niclosamide-inhibited xenograft tumor growth is potentiated by the inhibition of IGF signaling

We tested whether the in vivo anticancer activity of Niclosamide would be affected by silencing IGF-1R using the xenograft tumor model of human ovarian cancers. The firefly luciferase-tagged HeyA8 cells were first infected with AdR-siIGF1R or Ad-RGFP and injected subcutaneously into the flanks of athymic nude mice. Each infected group was further divided into Niclosamide-treated or vehicle treated subgroups. At three days post-injection, the animals were treated with Niclosamide $(10 \mathrm{mg} / \mathrm{kg}$ body weight) or vehicle control. Tumor growth was monitored weekly by using Xenogen bioluminescence imaging (Fig. 6a-i). Quantitative analysis of Xenogen imaging data indicated that Niclosamide or siIGF1R infection alone significantly inhibited tumor growth after two weeks when compared with the vehicle control group (Fig. 6a-ii). However, the AdR-silGF1R-infected HeyA8 cells and treated with Niclosamide exhibited the lowest signal among all four groups (Fig. 6a-ii). Xenogen imaging results were further confirmed by the retrieved tumor masses, indicating that the combination of siIGF1R and Niclosamide yielded smallest tumor masses, while Niclosamide or siIGF1R alone also showed apparent reduction of tumor sizes, compared with the RGFP alone group (Fig. 6b). H \& E staining of the retrieved tumor samples revealed that while the RGFP control group exhibited high cellular proliferation, Niclosamide and/ or siIGF1R treated tumor samples exhibited varied extents of necrosis relative to samples of the control group (Fig. 6c). Thus, these in vivo studies further substantiate the synergistic anticancer effects between Niclosamide and silencing IGF-1R.

\section{Discussion}

Although the 5-year survival rate for ovarian cancer patients has improved over the past two decades, the overall cure rate remains approximately $30 \%[1,3]$. Thus, there is a critical need to develop more effective and novel therapies to treat ovarian cancers. Our results have demonstrated that Niclosamide acts synergistically with the inhibition of IGF signaling to suppress proliferation and growth of ovarian cancer cells, suggesting that the repurposed Niclosamide may be combined with the targeted inhibition of IGF signaling as a potential novel and efficacious chemotherapy strategy for the clinical management of ovarian cancer.

Through a high throughput screening of over 1,200 clinically approved drugs using stem-like ovarian tumor-initiating cells (OTIC), Niclosamide was identified as one of the hits that targeted OTICs, possibly by disrupting multiple metabolic pathways including biogenetics, biogenesis, and redox regulation [31]. A combination of Niclosamide and carboplatin produced increased cytotoxicity compared to single agent treatment in most of the tumor cells isolated from the ascites of 34 ovarian cancer patients, and Wnt/ $\beta$-catenin 


\section{Cellular Physiology Cell Physiol Biochem 2016;39:871-888 and BiOChemistry \begin{tabular}{l|l} 
DOI: 10.1159/000447797 & $\begin{array}{l}\text { C) } 2016 \text { The Author(s). Published by S. Karger AG, Base } \\
\text { www.karger.com/cpb }\end{array}$
\end{tabular} \\ Deng et al.: Repurposing Niclosamide as an Anti-Ovarian Cancer Agent}

pathway was inhibited by Niclosamide in ovarian cancer cells [33], as in several other types of human cancers[15, 16, 21, 30, 32, 33, 76], although our pathway reporter analysis failed to demonstrate a significant inhibition of the Wnt signal pathway by Niclosamide. Another study indicates that Niclosamide may also exert its anticancer activity through inhibition of Wnt/ $\beta$-catenin target gene FGF1 in ovarian cancer [32]. More recently, efforts have been devoted to developing Niclosamide analogs with higher bioavailability [77] and/or designing more efficacious formulations for preclinical and eventually clinical studies [78].

Nonetheless, the molecular underpinning of Niclosamide-mediated anticancer activity remains to be fully elucidated although several studies have been carried out to delineate its potential molecular mechanisms [14]. It was shown that niclosamide can inhibit Notch signaling in K562 cells [28]. Niclosamide was identified as a candidate compound capable of stimulating autophagy and inhibiting mTORC1 signaling $[79,80]$. Consistent with our pathway reporter assay results, Niclosamide was shown to inactivate $\mathrm{NF \kappa B}$ pathway and generate reactive oxygen species in acute myelogenous leukemia stem cells [29]. Niclosamide was shown to inhibit STAT3 and consequently induced cell growth inhibition, apoptosis, and cell cycle arrest of the cancer cells with constitutively active STAT3 [81], which was shown to synergize with erlotinib against head and neck cancer [27], to overcome the acquired resistance to erlotinib in non-small cell lung cancer [19], and to reverse radioresistance of human lung cancer [20]. 100A4-induced metastasis formation in a mouse model of colon cancer was inhibited by niclosamide [17]. Furthermore, Niclosamide induced apoptosis, impaired metastasis and reduced immunosuppressive cells in breast cancer model [23].

Although our findings and other reports collectively demonstrate that Niclosamide has potent anticancer activity, it may not be used as a single agent therapy in human cancer. We found that Niclosamide can effectively target E2F, c-Myc and AP-1 pathways in human osteosarcoma cells [18]. In this study, we found that four pathway reporters including ELK1/ SRF, AP-1, MYC/MAX and NFKB, were significantly inhibited by Niclosamide in human ovarian cancer cells. The emerging evidence indicates that Niclosamide is a multiple-target agent. It's conceivable that Niclosamide may inhibit overlapping but distinct sets of cellular targets in different types of human cancers. Thus, identification and validation of cellular signaling pathways that may synergize or potentiate Niclosamide's anticancer activity will facilitate the translation of Niclosamide as an efficacious and attractive agent for the combination therapy of a broad range of human cancers including ovarian cancer.

In this study, we use the siRNA-mediated gene silencing strategy to specifically target IGF-1R signaling activity and explored a potential combination therapy with the respurposed Niclosamide in treating human ovarian cancers. The advantage of this approach is the high targeting specificity, while the disadvantage is the difficulty to effectively deliver such siRNA molecules into cancer cells. Targeting IGF signaling, especially IGF-1R activity, by either neutralizing/blocking antibodies or small molecule inhibitors has long been pursued as potential anticancer therapies [75, 82-84]. We have recently found that a naturally occurring IGF antagonist, IGFBP5, can inhibit tumor growth and metastasis $[41,75,85,86]$. While the early use of IGF neutralizing antibodies has been less successful, several IGF-1R blocking antibodies have moved to various phases of clinical trials $[83,87,88]$. Meanwhile, numerous IGF-1R small molecule inhibitors have shown promising results in clinical trials $[83,87$, 88]. Therefore, it's conceivable there is a great potential to develop efficacious anticancer therapies by combining Niclosamide and IGF-1R-targeting antibodies or small molecule inhibitors, which thus warrants further investigation.

In summary, we studied whether the anticancer activity of Niclosamide can be potentiated by inhibiting IGF signaling in human ovarian cancer cells. We found that Niclosamide alone was effective on inhibiting cell proliferation, cell migration, and cell cycle progression, and inducing apoptosis in human ovarian cancer cells, possibly by targeting multiple signaling pathways involved in ELK1/SRF, AP-1, MYC/MAX and NFKB. Silencing IGF-1R exerted a similar but weaker anti-proliferation activity than that of Niclosamide's. However, silencing IGF-1R significantly sensitized ovarian cancer cells to Niclosamideinduced anti-proliferative and anticancer activities both in vitro and in vivo. Therefore, our 


\section{Cellular Physiology Cell Physiol Biochem 2016;39:871-888 \begin{tabular}{cc|c|c|} 
DOI: 10.1159/000447797 & O 2016 The Author(s). Published by S. Karger AG, Basel \\
www.karger.com/cpb
\end{tabular} \\ Deng et al.: Repurposing Niclosamide as an Anti-Ovarian Cancer Agent}

findings strongly suggest that Niclosamide as a repurposed anticancer agent may be more efficacious when combined with agents that target other signaling pathways such as IGF signaling in the treatment of human cancers including ovarian cancer. Future studies should be directed towards testing Niclosamide as a combination therapy agent in preclinical and clinical studies.

\section{Acknowledgments}

We thank Dr. Ernest Lengyel of The University of Chicago Medical Center for the generous provision of ovarian cancer lines. The reported work was supported in part by research grants from the National Institutes of Health (AT004418, AR50142 to TCH and RCH), and the 973 Program of Ministry of Science and Technology (MOST) of China (\#2011CB707900 to TCH). This work was also supported in part by The University of Chicago Core Facility Subsidy grant from the National Center for Advancing Translational Sciences (NCATS) of the National Institutes of Health through Grant UL1 TR000430. Funding sources were not involved in the study design; in the collection, analysis and interpretation of data; in the writing of the report; and in the decision to submit the paper for publication.

\section{Disclosure Statement}

The authors declare no competing financial interests.

\section{References}

1 Bast RC Jr, Hennessy B, Mills GB: The biology of ovarian cancer: new opportunities for translation. Nat Rev Cancer 2009;9:415-428.

2 Kurman RJ, Shih Ie M: The origin and pathogenesis of epithelial ovarian cancer: a proposed unifying theory. Am J Surg Pathol 2010;34:433-443.

3 Raja FA, Chopra N, Ledermann JA: Optimal first-line treatment in ovarian cancer. Ann Oncol 2012;23:S $\mathrm{x} 118-127$.

4 McCluggage WG: Morphological subtypes of ovarian carcinoma: a review with emphasis on new developments and pathogenesis. Pathology 2011;43:420-432.

5 Lim D, Oliva E: Precursors and pathogenesis of ovarian carcinoma. Pathology 2013;45:229-242.

6 Ince TA, Sousa AD, Jones MA, Harrell JC, Agoston ES, Krohn M, Selfors LM, Liu W, Chen K, Yong M, Buchwald P, Wang B, Hale KS, Cohick E, Sergent P, Witt A, Kozhekbaeva Z, Gao S, Agoston AT, Merritt MA, Foster R, Rueda BR, Crum CP, Brugge JS, Mills GB: Characterization of twenty-five ovarian tumour cell lines that phenocopy primary tumours. Nat Commun 2015;6:7419.

7 Song N, Liu H, Ma X, Zhang S: Placental growth factor promotes metastases of ovarian cancer through MiR543-regulated MMP7. Cell Physiol Biochem 2015;37:1104-1112.

8 Ge T, Yin M, Yang M, Liu T, Lou G: MicroRNA-302b suppresses human epithelial ovarian cancer cell growth by targeting RUNX1. Cell Physiol Biochem 2014;34:2209-2220.

9 Teng Y, Zhao L, Zhang Y, Chen W, Li X: Id-1, a protein repressed by miR-29b, facilitates the TGFbeta1induced epithelial-mesenchymal transition in human ovarian cancer cells. Cell Physiol Biochem 2014;33:717-730.

10 He QZ, Luo XZ, Wang K, Zhou Q Ao H, Yang Y, Li SX, Li Y, Zhu HT, Duan T: Isolation and characterization of cancer stem cells from high-grade serous ovarian carcinomas. Cell Physiol Biochem 2014;33:173-184.

11 Chen Q, Qin R, Fang Y, Li H: Berberine Sensitizes Human Ovarian Cancer Cells to Cisplatin Through miR-93/ PTEN/Akt Signaling Pathway. Cell Physiol Biochem 2015;36:956-965.

12 Gupta SC, Sung B, Prasad S, Webb LJ, Aggarwal BB: Cancer drug discovery by repurposing: teaching new tricks to old dogs. Trends Pharmacol Sci 2013;34:508-517. 


\section{Cellular Physiology Cell Physiol Biochem 2016;39:871-888 \begin{tabular}{l|l|l}
\hline DOI: 10.1159/000447797 & $\begin{array}{l}\text { (c) 2016 The Author(s). Published by S. Karger AG, Basel } \\
\text { wwwwkarger.com/cpb }\end{array}$
\end{tabular} \\ Deng et al.: Repurposing Niclosamide as an Anti-Ovarian Cancer Agent}

13 Wang ZY, Quan Y, Zhang HY: Medical genetic inspirations for anticancer drug repurposing. Trends Pharmacol Sci 2014;35:1-3.

14 Li Y, Li PK, Roberts MJ, Arend RC, Samant RS, Buchsbaum DJ: Multi-targeted therapy of cancer by niclosamide: A new application for an old drug. Cancer Lett 2014;349:8-14.

15 Chen W, Chen M, Barak LS: Development of small molecules targeting the Wnt pathway for the treatment of colon cancer: a high-throughput screening approach. Am J Physiol Gastrointest Liver Physiol 2010;299:G293-300.

16 Osada T, Chen M, Yang XY, Spasojevic I, Vandeusen JB, Hsu D, Clary BM, Clay TM, Chen W, Morse MA, Lyerly HK: Antihelminth compound niclosamide downregulates Wnt signaling and elicits antitumor responses in tumors with activating APC mutations. Cancer Res 2011;71:4172-4182.

17 Sack U, Walther W, Scudiero D, Selby M, Kobelt D, Lemm M, Fichtner I, Schlag PM, Shoemaker RH, Stein U: Novel effect of antihelminthic Niclosamide on S100A4-mediated metastatic progression in colon cancer. J Natl Cancer Inst 2011;103:1018-1036.

18 Liao Z, Nan G, Yan Z, Zeng L, Deng Y, Ye J, Zhang Z, Qiao M, Li R, Denduluri S, Wang J, Wei Q, Geng N, Zhao L, Lu S, Wang X, Zhou G, Luu HH, Haydon RC, He TC, Wang Z: The Anthelmintic Drug Niclosamide Inhibits the Proliferative Activity of Human Osteosarcoma Cells by Targeting Multiple Signal Pathways. Curr Cancer Drug Targets 2015;15:726-738.

19 Li R, Hu Z, Sun SY, Chen ZG, Owonikoko TK, Sica GL, Ramalingam SS, Curran WJ, Khuri FR, Deng X: Niclosamide overcomes acquired resistance to erlotinib through suppression of STAT3 in non-small cell lung cancer. Mol Cancer Ther 2013;12:2200-2212.

20 You S, Li R, Park D, Xie M, Sica GL, Cao Y, Xiao ZQ Deng X: Disruption of STAT3 by niclosamide reverses radioresistance of human lung cancer. Mol Cancer Ther 2014;13:606-616.

21 Lu W, Lin C, Roberts MJ, Waud WR, Piazza GA, Li Y: Niclosamide suppresses cancer cell growth by inducing Wnt co-receptor LRP6 degradation and inhibiting the Wnt/beta-catenin pathway. PLoS One 2011;6:e29290.

22 Wang YC, Chao TK, Chang CC, Yo YT, Yu MH, Lai HC: Drug screening identifies niclosamide as an inhibitor of breast cancer stem-like cells. PLoS One 2013;8:e74538.

23 Ye T, Xiong Y, Yan Y, Xia Y, Song X, Liu L, Li D, Wang N, Zhang L, Zhu Y, Zeng J, Wei Y, Yu L: The anthelmintic drug niclosamide induces apoptosis, impairs metastasis and reduces immunosuppressive cells in breast cancer model. PLoS One 2014;9:e85887.

24 Londono-Joshi AI, Arend RC, Aristizabal L, Lu W, Samant RS, Metge BJ, Hidalgo B, Grizzle WE, Conner M, Forero-Torres A, Lobuglio AF, Li Y, Buchsbaum DJ: Effect of niclosamide on basal-like breast cancers. Mol Cancer Ther 2014;13:800-811.

25 Liu C, Lou W, Zhu Y, Nadiminty N, Schwartz CT, Evans CP, Gao AC: Niclosamide inhibits androgen receptor variants expression and overcomes enzalutamide resistance in castration-resistant prostate cancer. Clin Cancer Res 2014;20:3198-3210.

26 Wieland A, Trageser D, Gogolok S, Reinartz R, Hofer H, Keller M, Leinhaas A, Schelle R, Normann S, Klaas L, Waha A, Koch P, Fimmers R, Pietsch T, Yachnis AT, Pincus DW, Steindler DA, Brustle O, Simon M, Glas M, Scheffler B: Anticancer effects of niclosamide in human glioblastoma. Clin Cancer Res 2013;19:4124-4136.

27 Li R, You S, Hu Z, Chen ZG, Sica GL, Khuri FR, Curran WJ, Shin DM, Deng X: Inhibition of STAT3 by niclosamide synergizes with erlotinib against head and neck cancer. PLoS One 2013;8:e74670.

28 Wang AM, Ku HH, Liang YC, Chen YC, Hwu YM, Yeh TS: The autonomous notch signal pathway is activated by baicalin and baicalein but is suppressed by niclosamide in K562 cells. J Cell Biochem 2009;106:682692.

29 Jin Y, Lu Z, Ding K, Li J, Du X, Chen C, Sun X, Wu Y, Zhou J, Pan J: Antineoplastic mechanisms of niclosamide in acute myelogenous leukemia stem cells: inactivation of the NF-kappaB pathway and generation of reactive oxygen species. Cancer Res 2010;70:2516-2527.

30 Ono M, Yin P, Navarro A, Moravek MB, Coon VJ, Druschitz SA, Gottardi CJ, Bulun SE: Inhibition of canonical WNT signaling attenuates human leiomyoma cell growth. Fertil Steril 2014;101:1441-1449.

31 Yo YT, Lin YW, Wang YC, Balch C, Huang RL, Chan MW, Sytwu HK, Chen CK, Chang CC, Nephew KP, Huang T, Yu MH, Lai HC: Growth inhibition of ovarian tumor-initiating cells by niclosamide. Mol Cancer Ther 2012;11:1703-1712. 


\section{Cellular Physiology Cell Physiol Biochem 2016;39:871-888 \begin{tabular}{l|l|l|l|l}
\hline DOI: 10.1159/000447797 & (c) 2016 The Author(s). Published by S. Karger AG, Basel \\
and Biochemistry
\end{tabular}

32 King ML, Lindberg ME, Stodden GR, Okuda H, Ebers SD, Johnson A, Montag A, Lengyel E, MacLean Ii JA, Hayashi K: WNT7A/beta-catenin signaling induces FGF1 and influences sensitivity to niclosamide in ovarian cancer. Oncogene 2015;34:3452-3462.

33 Arend RC, Londono-Joshi AI, Samant RS, Li Y, Conner M, Hidalgo B, Alvarez RD, Landen CN, Straughn JM, Buchsbaum DJ: Inhibition of Wnt/beta-catenin pathway by niclosamide: a therapeutic target for ovarian cancer. Gynecol Oncol 2014;134:112-120.

34 Wu N, Zhang H, Deng F, Li R, Zhang W, Chen X, Wen S, Wang N, Zhang J, Yin L, Liao Z, Zhang Z, Zhang Q, Yan Z, Liu W, Wu D, Ye J, Deng Y, Yang K, Luu HH, Haydon RC, He TC: Overexpression of Ad5 precursor terminal protein accelerates recombinant adenovirus packaging and amplification in HEK-293 packaging cells. Gene Ther 2014;21:629-637.

35 Wang N, Zhang H, Zhang BQ, Liu W, Zhang Z, Qiao M, Zhang H, Deng F, Wu N, Chen X, Wen S, Zhang J, Liao Z, Zhang Q, Yan Z, Yin L, Ye J, Deng Y, Luu HH, Haydon RC, Liang H, He TC: Adenovirus-mediated efficient gene transfer into cultured three-dimensional organoids. PLoS One 2014;9:e93608.

36 Lamplot JD, Liu B, Yin L, Zhang W, Wang Z, Luther G, Wagner E, Li R, Nan G, Shui W, Yan Z, Rames R, Deng F, Zhang H, Liao Z, Liu W, Zhang J, Zhang Z, Zhang Q, Ye J, Deng Y, Qiao M, Haydon RC, Luu HH, Angeles J, Shi LL, He TC, Ho SH: Reversibly Immortalized Mouse Articular Chondrocytes Acquire Long-Term Proliferative Capability while Retaining Chondrogenic Phenotype. Cell Transplant 2015;24:1053-1066.

37 Wen S, Zhang H, Li Y, Wang N, Zhang W, Yang K, Wu N, Chen X, Deng F, Liao Z, Zhang J, Zhang Q, Yan Z, Liu W, Zhang Z, Ye J, Deng Y, Zhou G, Luu HH, Haydon RC, Shi LL, He TC, Wei G: Characterization of constitutive promoters for piggyBac transposon-mediated stable transgene expression in mesenchymal stem cells (MSCs). PLoS One 2014;9:e94397.

38 Haydon RC, Zhou L, Feng T, Breyer B, Cheng H, Jiang W, Ishikawa A, Peabody T, Montag A, Simon MA, He TC: Nuclear receptor agonists as potential differentiation therapy agents for human osteosarcoma. Clin Cancer Res 2002;8:1288-1294.

39 Luo X, Chen J, Song WX, Tang N, Luo J, Deng ZL, Sharff KA, He G, Bi Y, He BC, Bennett E, Huang J, Kang Q, Jiang W, Su Y, Zhu GH, Yin H, He Y, Wang Y, Souris JS, Chen L, Zuo GW, Montag AG, Reid RR, Haydon RC, Luu $\mathrm{HH}, \mathrm{He}$ TC: Osteogenic BMPs promote tumor growth of human osteosarcomas that harbor differentiation defects. Lab Invest 2008;88:1264-1277.

40 Su Y, Luo X, He BC, Wang Y, Chen L, Zuo GW, Liu B, Bi Y, Huang J, Zhu GH, He Y, Kang Q, Luo J, Shen J, Chen J, Jin X, Haydon RC, He TC, Luu HH: Establishment and characterization of a new highly metastatic human osteosarcoma cell line. Clin Exp Metastasis 2009;26:599-610.

41 Su Y, Wagner ER, Luo Q, Huang J, Chen L, He BC, Zuo GW, Shi Q, Zhang BQ, Zhu G, Bi Y, Luo J, Luo X, Kim SH, Shen J, Rastegar F, Huang E, Gao Y, Gao JL, Yang K, Wietholt C, Li M, Qin J, Haydon RC, He TC, Luu $\mathrm{HH}$ : Insulin-like growth factor binding protein 5 suppresses tumor growth and metastasis of human osteosarcoma. Oncogene 2011;30:3907-3917.

42 He BC, Gao JL, Zhang BQ Luo Q, Shi Q Kim SH, Huang E, Gao Y, Yang K, Wagner ER, Wang L, Tang N, Luo J, Liu X, Li M, Bi Y, Shen J, Luther G, Hu N, Zhou Q, Luu HH, Haydon RC, Zhao Y, He TC: Tetrandrine inhibits Wnt/beta-catenin signaling and suppresses tumor growth of human colorectal cancer. Mol Pharmacol 2011;79:211-219.

43 Wang N, Zhang W, Cui J, Zhang H, Chen X, Li R, Wu N, Chen X, Wen S, Zhang J, Yin L, Deng F, Liao Z, Zhang Z, Zhang Q Yan Z, Liu W, Ye J, Deng Y, Wang Z, Qiao M, Luu HH, Haydon RC, Shi LL, Liang H, He TC: The piggyBac Transposon-Mediated Expression of SV40 T Antigen Efficiently Immortalizes Mouse Embryonic Fibroblasts (MEFs). PLoS One 2014;9:e97316.

44 Denduluri SK, Scott B, Lamplot JD, Yin L, Yan Z, Wang Z, Ye J, Wang J, Wei Q, Mohammed MK, Haydon RC, Kang RW, He TC, Athiviraham A, Ho SH, Shi LL: Immortalized Mouse Achilles Tenocytes Demonstrate Long-Term Proliferative Capacity While Retaining Tenogenic Properties. Tissue Eng Part C Methods 2016;22:280-289.

45 He BC, Chen L, Zuo GW, Zhang W, Bi Y, Huang J, Wang Y, Jiang W, Luo Q Shi Q, Zhang BQ Liu B, Lei X, Luo J, Luo X, Wagner ER, Kim SH, He CJ, Hu Y, Shen J, Zhou Q, Rastegar F, Deng ZL, Luu HH, He TC, Haydon RC: Synergistic antitumor effect of the activated PPARgamma and retinoid receptors on human osteosarcoma. Clin Cancer Res 2010;16:2235-2245. 


\section{Cellular Physiology Cell Physiol Biochem 2016;39:871-888 \begin{tabular}{l|l|l}
\hline DOI: 10.1159/000447797 & $\begin{array}{l}\text { C) 2016 The Author(s). Published by S. Karger AG, Basel } \\
\text { www.karger.com/cpb }\end{array}$ \\
\hline
\end{tabular} \\ Deng et al.: Repurposing Niclosamide as an Anti-Ovarian Cancer Agent}

46 Li R, Zhang W, Cui J, Shui W, Yin L, Wang Y, Zhang H, Wang N, Wu N, Nan G, Chen X, Wen S, Deng F, Zhou G, Liao Z, Zhang J, Zhang Q, Yan Z, Liu W, Zhang Z, Ye J, Deng Y, Luu HH, Haydon RC, He TC, Deng ZL: Targeting BMP9-promoted human osteosarcoma growth by inactivation of notch signaling. Curr Cancer Drug Targets 2014;14:274-285.

47 Cheng H, Jiang W, Phillips FM, Haydon RC, Peng Y, Zhou L, Luu HH, An N, Breyer B, Vanichakarn P, Szatkowski JP, Park JY, He TC: Osteogenic activity of the fourteen types of human bone morphogenetic proteins (BMPs). J Bone Joint Surg Am 2003;85-A:1544-1552.

48 Kang Q Song WX, Luo Q, Tang N, Luo J, Luo X, Chen J, Bi Y, He BC, Park JK, Jiang W, Tang Y, Huang J, Su Y, Zhu GH, He Y, Yin H, Hu Z, Wang Y, Chen L, Zuo GW, Pan X, Shen J, Vokes T, Reid RR, Haydon RC, Luu HH, He TC: A comprehensive analysis of the dual roles of BMPs in regulating adipogenic and osteogenic differentiation of mesenchymal progenitor cells. Stem Cells Dev 2009;18:545-559.

49 Kang Q Sun MH, Cheng H, Peng Y, Montag AG, Deyrup AT, Jiang W, Luu HH, Luo J, Szatkowski JP, Vanichakarn P, Park JY, Li Y, Haydon RC, He TC: Characterization of the distinct orthotopic bone-forming activity of 14 BMPs using recombinant adenovirus-mediated gene delivery. Gene Ther 2004;11:1312-1320.

50 Luo J, Deng ZL, Luo X, Tang N, Song WX, Chen J, Sharff KA, Luu HH, Haydon RC, Kinzler KW, Vogelstein B, He TC: A protocol for rapid generation of recombinant adenoviruses using the AdEasy system. Nat Protoc 2007;2:1236-1247.

51 Luo Q, Kang Q, Song WX, Luu HH, Luo X, An N, Luo J, Deng ZL, Jiang W, Yin H, Chen J, Sharff KA, Tang N, Bennett E, Haydon RC, He TC: Selection and validation of optimal siRNA target sites for RNAi-mediated gene silencing. Gene 2007;395:160-169.

52 Deng F, Chen X, Liao Z, Yan Z, Wang Z, Deng Y, Zhang Q, Zhang Z, Ye J, Qiao M, Li R, Denduluri S, Wang J, Wei Q Li M, Geng N, Zhao L, Zhou G, Zhang P, Luu HH, Haydon RC, Reid RR, Yang T, He TC: A Simplified and Versatile System for the Simultaneous Expression of Multiple siRNAs in Mammalian Cells Using Gibson DNA Assembly. PLoS One 2014;9:e113064.

53 Zhang H, Wang J, Deng F, Huang E, Yan Z, Wang Z, Deng Y, Zhang Q, Zhang Z, Ye J, Qiao M, Li R, Wang J, Wei Q, Zhou G, Luu HH, Haydon RC, He TC, Deng F: Canonical Wnt signaling acts synergistically on BMP9induced osteo/odontoblastic differentiation of stem cells of dental apical papilla (SCAPs). Biomaterials 2015;39:145-154.

54 Kong Y, Zhang H, Chen X, Zhang W, Zhao C, Wang N, Wu N, He Y, Nan G, Zhang H, Wen S, Deng F, Liao Z, Wu D, Zhang J, Qin X, Haydon RC, Luu HH, He TC, Zhou L: Destabilization of Heterologous Proteins Mediated by the GSK3beta Phosphorylation Domain of the beta-Catenin Protein. Cell Physiol Biochem 2013;32:11871199.

55 Liu X, Qin J, Luo Q, Bi Y, Zhu G, Jiang W, Kim SH, Li M, Su Y, Nan G, Cui J, Zhang W, Li R, Chen X, Kong Y, Zhang J, Wang J, Rogers MR, Zhang H, Shui W, Zhao C, Wang N, Liang X, Wu N, He Y, Luu HH, Haydon RC, Shi LL, Li T, He TC, Li M: Cross-talk between EGF and BMP9 signalling pathways regulates the osteogenic differentiation of mesenchymal stem cells. J Cell Mol Med 2013;17:1160-1172.

56 Wang Y, Hong S, Li M, Zhang J, Bi Y, He Y, Liu X, Nan G, Su Y, Zhu G, Li R, Zhang W, Wang J, Zhang H, Kong Y, Shui W, Wu N, He Y, Chen X, Luu HH, Haydon RC, Shi LL, He TC, Qin J: Noggin resistance contributes to the potent osteogenic capability of BMP9 in mesenchymal stem cells. J Orthop Res 2013;31:1796-1803.

57 Gao Y, Huang E, Zhang H, Wang J, Wu N, Chen X, Wang N, Wen S, Nan G, Deng F, Liao Z, Wu D, Zhang B, Zhang J, Haydon RC, Luu HH, Shi LL, He TC: Crosstalk between Wnt/beta-Catenin and Estrogen Receptor Signaling Synergistically Promotes Osteogenic Differentiation of Mesenchymal Progenitor Cells. PLoS One 2013;8:e82436.

58 Tang N, Song WX, Luo J, Luo X, Chen J, Sharff KA, Bi Y, He BC, Huang JY, Zhu GH, Su YX, Jiang W, Tang M, He Y, Wang Y, Chen L, Zuo GW, Shen J, Pan X, Reid RR, Luu HH, Haydon RC, He TC: BMP9-induced osteogenic differentiation of mesenchymal progenitors requires functional canonical Wnt/beta-catenin signaling. J Cell Mol Med 2009;13:2448-2464.

59 Ye J, Wang J, Zhu Y, Wei Q, Wang X, Yang J, Tang S, Liu H, Fan J, Zhang F, Farina EM, Mohammed MK, Zou Y, Song D, Liao J, Huang J, Guo D, Lu M, Liu F, Liu J, Li L, Ma C, Hu X, Haydon RC, Lee MJ, Reid RR, Ameer GA, Yang L, He TC: A thermoresponsive polydiolcitrate-gelatin scaffold and delivery system mediates effective bone formation from BMP9-transduced mesenchymal stem cells. Biomed Mater 2016;11:025021. 


\section{Cellular Physiology Cell Physiol Biochem 2016;39:871-888 \begin{tabular}{l|l|l|}
\hline DOI: 10.1159/000447797 & $\begin{array}{l}\text { C) } 2016 \text { The Author(s). Published by S. Karger AG, Basel } \\
\text { www.karger.com/cpb }\end{array}$
\end{tabular}

60 Zhao C, Wu N, Deng F, Zhang H, Wang N, Zhang W, Chen X, Wen S, Zhang J, Yin L, Liao Z, Zhang Z, Zhang Q, Yan Z, Liu W, Wu D, Ye J, Deng Y, Zhou G, Luu HH, Haydon RC, Si W, He TC: Adenovirus-mediated gene transfer in mesenchymal stem cells can be significantly enhanced by the cationic polymer polybrene. PLoS One 2014;9:e92908.

61 Gao JL, Lv GY, He BC, Zhang BQ, Zhang H, Wang N, Wang CZ, Du W, Yuan CS, He TC: Ginseng saponin metabolite 20(S)-protopanaxadiol inhibits tumor growth by targeting multiple cancer signaling pathways. Oncol Rep 2013;30:292-298.

62 Li M, Chen Y, Bi Y, Jiang W, Luo Q, He Y, Su Y, Liu X, Cui J, Zhang W, Li R, Kong Y, Zhang J, Wang J, Zhang H, Shui W, Wu N, Zhu J, Tian J, Yi QJ, Luu HH, Haydon RC, He TC, Zhu GH: Establishment and characterization of the reversibly immortalized mouse fetal heart progenitors. Int J Med Sci 2013;10:1035-1046.

63 Deng Y, Zhang J, Wang Z, Yan Z, Qiao M, Ye J, Wei Q, Wang J, Wang X, Zhao L, Lu S, Tang S, Mohammed MK, Liu H, Fan J, Zhang F, Zou Y, Liao J, Qi H, Haydon RC, Luu HH, He TC, Tang L: Antibiotic monensin synergizes with EGFR inhibitors and oxaliplatin to suppress the proliferation of human ovarian cancer cells. Sci Rep 2015;5:17523.

64 Untergasser A, Cutcutache I, Koressaar T, Ye J, Faircloth BC, Remm M, Rozen SG: Primer3--new capabilities and interfaces. Nucleic Acids Res 2012;40:e115.

65 Zhang Q, Wang J, Deng F, Yan Z, Xia Y, Wang Z, Ye J, Deng Y, Zhang Z, Qiao M, Li R, Denduluri SK, Wei Q, Zhao L, Lu S, Wang X, Tang S, Liu H, Luu HH, Haydon RC, He TC, Jiang L: TqPCR: A Touchdown qPCR Assay with Significantly Improved Detection Sensitivity and Amplification Efficiency of SYBR Green qPCR. PLoS One 2015;10:e0132666.

66 Chen X, Cui J, Yan Z, Zhang H, Chen X, Wang N, Shah P, Deng F, Zhao C, Geng N, Li M, Denduluri SK, Haydon RC, Luu HH, Reid RR, He TC: Sustained high level transgene expression in mammalian cells mediated by the optimized piggyBac transposon system. Genes Dis 2015;2:96-105.

67 Yan Z, Yin L, Wang Z, Ye J, Zhang Z, Li R, Denduluri SK, Wang J, Wei Q, Zhao L, Lu S, Wang X, Tang S, Shi LL, Lee MJ, He TC, Deng ZL: A Novel Organ Culture Model of Mouse Intervertebral Disc Tissues. Cells Tissues Organs 2016;201:38-50.

68 Tumova L, Pombinho AR, Vojtechova M, Stancikova J, Gradl D, Krausova M, Sloncova E, Horazna M, Kriz V, Machonova O, Jindrich J, Zdrahal Z, Bartunek P, Korinek V: Monensin inhibits canonical Wnt signaling in human colorectal cancer cells and suppresses tumor growth in multiple intestinal neoplasia mice. Mol Cancer Ther 2014;13:812-822.

69 Arend RC, Londono-Joshi AI, Straughn JM, Jr., Buchsbaum DJ: The Wnt/beta-catenin pathway in ovarian cancer: a review. Gynecol Oncol 2013;131:772-779.

70 Yang K, Wang X, Zhang H, Wang Z, Nan G, Li Y, Zhang F, Mohammed MK, Haydon RC, Luu HH, Bi Y, He TC: The evolving roles of canonical WNT signaling in stem cells and tumorigenesis: implications in targeted cancer therapies. Lab Invest 2016;96:116-136.

71 Mohammed MK, Shao C, Wang J, Wei Q, Wang X, Collier Z, Tang S, Liu H, Zhang F, Huang J, Guo D, Lu M, Liu F, Liu J, Ma C, Shi LL, Athiviraham A, He TC, Lee MJ: Wnt/beta-catenin signaling plays an ever-expanding role in stem cell self-renewal, tumorigenesis and cancer chemoresistance. Genes Dis 2016;3:11-40.

72 He BC, Gao JL, Luo X, Luo J, Shen J, Wang L, Zhou Q, Wang YT, Luu HH, Haydon RC, Wang CZ, Du W, Yuan CS, He TC, Zhang BQ: Ginsenoside Rg3 inhibits colorectal tumor growth through the down-regulation of Wnt/ ss-catenin signaling. Int J Oncol 2011;38:437-445.

73 Arteaga CL, Engelman JA: ERBB receptors: from oncogene discovery to basic science to mechanism-based cancer therapeutics. Cancer Cell 2014;25:282-303.

74 Pollak M: The insulin and insulin-like growth factor receptor family in neoplasia: an update. Nat Rev Cancer 2012;12:159-169.

75 Denduluri SK, Olumuyiwa Idowu O, Wang Z, Liao Z, Yan Z, Mohammed MK, Ye J, Wei Q, Wang J, Zhao L, Luu HH: Insulin-like growth factor (IGF) signaling in tumorigenesis and the development of cancer drug resistance. Genes Dis 2015;2:13-25.

76 Mook RA, Jr., Chen M, Lu J, Barak LS, Lyerly HK, Chen W: Small molecule modulators of Wnt/beta-catenin signaling. Bioorg Med Chem Lett 2013;23:2187-2191.

77 Walters Haygood CL, Arend RC, Gangrade A, Chettiar S, Regan N, Hassmann CJ, 2nd, Li PK, Hidalgo B, Straughn JM, Jr., Buchsbaum DJ: Niclosamide Analogs for Treatment of Ovarian Cancer. Int J Gynecol Cancer 2015;25:1377-1385. 


\section{Cellular Physiology Cell Physiol Biochem 2016;39:871-888 \begin{tabular}{l|l} 
DOI: 10.1159/000447797 & $\begin{array}{l}\text { O 2016 The Author(s). Published by S. Karger AG, Basel } \\
\text { www.karger.com/cpb }\end{array}$
\end{tabular} \\ Deng et al.: Repurposing Niclosamide as an Anti-Ovarian Cancer Agent}

78 Lin CK, Bai MY, Hu TM, Wang YC, Chao TK, Weng SJ, Huang RL, Su PH, Lai HC: Preclinical evaluation of a nanoformulated antihelminthic, niclosamide, in ovarian cancer. Oncotarget 2016;7:8993-9006.

79 Balgi AD, Fonseca BD, Donohue E, Tsang TC, Lajoie P, Proud CG, Nabi IR, Roberge M: Screen for chemical modulators of autophagy reveals novel therapeutic inhibitors of mTORC1 signaling. PLoS One 2009; 4:e7124.

80 Fonseca BD, Diering GH, Bidinosti MA, Dalal K, Alain T, Balgi AD, Forestieri R, Nodwell M, Rajadurai CV, Gunaratnam C, Tee AR, Duong F, Andersen RJ, Orlowski J, Numata M, Sonenberg N, Roberge M: Structureactivity analysis of niclosamide reveals potential role for cytoplasmic $\mathrm{pH}$ in control of mammalian target of rapamycin complex 1 (mTORC1) signaling. J Biol Chem 2012;287:17530-17545.

81 Ren X, Duan L, He Q, Zhang Z, Zhou Y, Wu D, Pan J, Pei D, Ding K: Identification of Niclosamide as a New Small-Molecule Inhibitor of the STAT3 Signaling Pathway. ACS Med Chem Lett 2010;1:454-459.

82 Zha J, Lackner MR: Targeting the insulin-like growth factor receptor-1R pathway for cancer therapy. Clin Cancer Res 2010;16:2512-2517.

83 Singh P, Alex JM, Bast F: Insulin receptor (IR) and insulin-like growth factor receptor 1 (IGF-1R) signaling systems: novel treatment strategies for cancer. Med Oncol 2014;31:805.

84 Fox EM, Kuba MG, Miller TW, Davies BR, Arteaga CL: Autocrine IGF-I/insulin receptor axis compensates for inhibition of AKT in ER-positive breast cancer cells with resistance to estrogen deprivation. Breast Cancer Res 2013;15:R55.

85 Luther GA, Lamplot J, Chen X, Rames R, Wagner ER, Liu X, Parekh A, Huang E, Kim SH, Shen J, Haydon RC, He TC, Luu HH: IGFBP5 Domains Exert Distinct Inhibitory Effects on the Tumorigenicity and Metastasis of Human Osteosarcoma. Cancer Lett 2013;336:222-230.

86 Denduluri SK, Wang Z, Yan Z, Wang J, Wei Q Mohammed MK, Haydon RC, Luu HH, He TC: Molecular pathogenesis and therapeutic strategies of human osteosarcoma. J Biomed Res 2015;30:

87 Chen HX, Sharon E: IGF-1R as an anti-cancer target--trials and tribulations. Chin J Cancer 2013;32:242-252.

88 King H, Aleksic T, Haluska P, Macaulay VM: Can we unlock the potential of IGF-1R inhibition in cancer therapy? Cancer Treat Rev 2014;40:1096-1105. 